\title{
A Place to Go: How Neighborhood Organizations Structure the Lives of the Urban Poor and Negotiate Social Policy
}

\section{Gijs Custers and Godfried Engbersen}

Erasmus University Rotterdam

\begin{abstract}
Neighborhood organizations are believed to be important in alleviating the plight of the urban poor. This study examines how different types of neighborhood organizations affect the lives of the urban poor in low-income neighborhoods. Qualitative field work was conducted in a faith-based organization, a professional welfare organization, and a volunteer-based organization. Our findings indicate the ways in which these organizations foster social relations between participants, provide daily structure to nonworking individuals, and connect people to other organizations and systemic bodies such as the labor market or local government. In addition, the relation between the neighborhood organizations and social policy has been considered, paying close attention to policy processes of decentralization, responsibilization, and social innovation. A central aim of this study is thus to analyze how neighborhood organizations mediate between social processes at the micro-level and macro-level systemic forces. Finally, this study discusses how considering the socially productive role of local organizations may advance neighborhood effects studies.
\end{abstract}

Keywords: neighborhood organizations; social policy; neighborhood effects studies; social capital; urban poor. 


\section{Introduction}

Even though the relevance of the 'neighborhood' is continuously questioned in a globalizing world (Sampson, 2012; van Kempen \& Wissink, 2014), research shows that local organizations in the neighborhood play an important role for the social capital, health, and wellbeing of residents (e.g. Curley, 2010a; Klinenberg, 2015; Nast \& Blokland, 2014). Neighborhood organizations seem especially relevant to the urban poor as they may mitigate the disadvantaging effects of inequalities in the labor market, changing welfare policies, and restricted access to housing (see Oosterlynck et al., 2013). Allard and Small (2013) therefore argue that research should focus more on (local) organizations that shape the lives of the urban poor, since they mediate people's living conditions in particular ways. The limited ability of neighborhood effects studies to explain associations between neighborhood indicators and individual outcomes strengthens this argument, as neighborhood organizations may form a social mechanism that connects the neighborhood and the individual level (cf. Galster, 2012; Sampson, 2012; Sharkey \& Faber, 2014). Hence, neighborhood organizations potentially explain why residents with similar characteristics (e.g. socioeconomic status) in comparable neighborhoods differ considerably with regard to life chances (Klinenberg, 2015; Marwell, 2007; Small, 2009).

Yet, studies that quantify the effect of neighborhood organizations (e.g. Curley, 2010b; Gilster, 2017) produce little insight into how neighborhood organizations create social capital, lead to employment or foster wellbeing amongst residents in low-income neighborhoods (Curley, 2010a; Nast \& Blokland, 2014; Pinkster, 2007). Few studies examine the ways in which neighborhood organizations advance the lives of the urban poor and thus more in-depth research is needed (Small, 2009; van Eijk, 2010). In this study we therefore investigate how three neighborhood organizations affect the lives of residents in low-income neighborhoods in the Dutch city of Rotterdam. These organizations vary by type, as they have different structures, goals, and serve specific groups (cf. Anheier, 2005). We conducted qualitative research in a faith-based organization, a professional welfare organization, and a volunteerbased organization. Although these organizations differ from each other in type, they have similar 
functions such as fostering relations between residents (Bosch, 2016; van Eijk, 2010), providing daily structure (Jahoda, 1982), and connecting residents to other organizations (Small, 2009; Szreter \& Woolcock, 2004). Our aim is not to explain different outcomes between neighborhoods. Rather, we study the mechanisms by which neighborhood organizations influence their participants and how participants experience their involvement.

Neighborhood organizations are generally conceptualized as meso-level institutions (McQuarrie \& Marwell, 2009; Rich, 1979; Smith \& Lipsky, 1993). They deal with higher-level actors such as the nation state, local government, and charities, from whom they often receive the funds needed to conduct their daily operations. In turn, organizations in low-income neighborhoods structure the lives and social relations of underemployed or unemployed individuals (Marwell, 2007). These organizations therefore deal with policies related to work, welfare, and civil society. Over the past few decades, there have been substantial shifts in these policy fields. We have identified three central trends: decentralization, responsibilization, and social innovation (in general, see Andreotti et al., 2012). The consequences of these trends can be observed in policies at the local level in Rotterdam. Conditions for receiving social assistance have become stricter and recipients are nowadays obliged to 'do something useful in return' for society (Fenger \& Broekema, 2019; Kampen et al., 2019; Veldboer et al., 2015; cf. Mead, 1986). At the same time, self-organization and social innovation initiated by citizens are increasingly celebrated by government officials and encouraged through local subsidies (Uitermark, 2015). We investigate how such changes in local policy affect both neighborhood organizations (meso level) and their participants (individual level).

Our central aim is twofold. First, we show how different neighborhood organizations in lowincome neighborhoods affect and structure the lives of residents and how residents experience their involvement. Since these organizations vary in their main activities, we demonstrate how every type of organization plays a distinct role in the neighborhood, but also how each organization has its limitations. 
Second, we examine how neighborhood organizations relate to extra-neighborhood actors and how organizations and their participants are influenced by local policy.

\section{The missing link in neighborhood effects studies}

The increasing interest in neighborhood organizations can be partly understood as a response to the limited ability of neighborhood effects studies to explain associations between population characteristics of neighborhoods and individual outcomes. For example, some studies suggest that living in mixedincome neighborhoods, compared to living in low-income neighborhoods, might be more beneficial for people's labor market position (e.g. Pinkster, 2009). Such studies argue that people gain resources through several mechanisms related to social capital in the neighborhood (see Galster, 2012). However, these social mechanisms are rarely directly tested in quantitative studies (although see Custers, 2019; Miltenburg, 2015) and quantitative neighborhood effects studies are therefore criticized for providing little insight into neighborhood processes (e.g. Slater, 2013).

Other research focuses on factors that contribute to social capital in the neighborhood. A clear link exists between neighborhood socioeconomic status and social capital indicators such as social networks, trust, and communal involvement (e.g. Custers et al., 2019; Letki, 2008). Yet, some studies indicate that neighborhood resources, such as recreation facilities, public spaces, grocery stores, and social services, at least partly mediate this relationship (Curley, 2010a, 2010b; Gilster, 2017; van Bergeijk et al., 2008). The presence of these resources provides more opportunities for social interaction between residents. Although there tend to be more organizational resources in affluent neighborhoods, thereby explaining why social capital is higher in these neighborhoods, the relation between neighborhood socioeconomic status and social capital is not always fully mediated by these resources, suggesting neighborhood resources are a separate dimension that differentiate neighborhoods (Gilster, 2017; Small, 2009). To better understand how this (partial) mediation occurs, and thus why neighborhood 
organizations form a 'missing link' (Allard \& Small, 2013), it is necessary to examine the ways in which neighborhood organizations create social capital (Curley, 2010a; Nast \& Blokland, 2014; Pinkster, 2007). McQuarrie and Marwell (2009: 247-248) underline that neighborhood organizations are 'socially productive', meaning organizations have an independent role in the production, reproduction, and arrangement of urban social relations, neighborhood conditions, and individual outcomes and identities. They are not mere aggregations of social interaction or derivates of extra-organizational social processes (see McQuarrie \& Marwell, 2009). Moreover, neighborhood organizations have different functions and produce social relations in distinct ways, which implies that organizations affect different subpopulations in the neighborhood.

\section{Research on neighborhood organizations}

What exactly defines a neighborhood organization is up for debate (Allard \& Small, 2013; McQuarrie \& Marwell, 2009). Neighborhood organizations cover a broad range of local institutions that are often hybrid in character and have different organizational goals. Examples that are frequently mentioned include community centers, churches, childcare centers, libraries, sport associations, welfare offices, resident associations, and schools. We adopt the criteria of the structural-operational definition of nonprofit organizations by Anheier (2005) to characterize neighborhood organizations. According to these criteria, organization must be 1) institutionalized to some extent 2) institutionally separate from government, and therefore not part of the government apparatus 3) self-governing, that is, in control of their own activities 4) non-profit-distributing, meaning profits are not distributed to any stakeholders and 5) that their members should be involved on a voluntary basis to some degree. In addition, we assume that neighborhood organizations have a physical location in the neighborhood, direct their services towards the neighborhood, and that most people participating in them are living in the near vicinity. 
Most neighborhood organizations stimulate some form of societal participation, which may vary from countering social isolation (e.g. Klinenberg, 2015) to helping people obtain employment (e.g. Pinkster, 2007). We focus on three aspects of neighborhood organizations that are central to encouraging societal participation: fostering social relations, providing daily structure, and linking to other organizations. First, neighborhood organizations play a key role in connecting residents to each other. As van Eijk (2010) illustrates, relations between neighbors do not begin spontaneously on the street. These relations develop in settings that facilitate regular interaction between neighbors. How this interaction is structured, depends on the type of neighborhood organization and the activities that are organized. For example, Wessendorf (2014) shows that in a 'superdiverse' neighborhood, weekly coffee mornings at a local primary school create opportunities for parents to meet and socialize. Even though the parents have very different backgrounds, during these meetings they connect with each other on several issues such as the children's upbringing, unemployment, and changes in the neighborhood.

Second, a very basic aspect of neighborhood organizations is that they provide a daily structure for people who are economically inactive, such as the unemployed, social assistance recipients, retirees or caregivers. For these groups, neighborhood organizations fulfill some of the 'latent' functions of employment, including the imposition of a time structure, the enlargement of the scope of social experience into areas less emotionally charged than family life, participation in a collective purpose or effort, the assignment by virtue of employment of status and identity, and required regular activity (Jahoda, 1982: 59). ${ }^{1}$ In their study of voluntary organizations, Baines and Hardill (2008) point out how volunteers perceive their involvement as 'work' given the commitment it requires. Many volunteers structure their weekday routine around volunteering and for those unable to perform paid work - due to age, disability or health issues - volunteering is an important source of personal identity.

Finally, neighborhood organizations can connect their participants to other organizations so they may obtain resources such as information, services or material goods. Small (2009) calls these connections 'organizational ties', which are connections people make to other organizations that are 
brokered by the organization in which they participate. For example, his study demonstrates how childcare centers help parents gain knowledge about child nutrition by putting them in touch with an expert from outside. A related concept is 'linking' social capital, which stands for the extent to which individuals build relationships with institutions and individuals who have relative power over them (Hawkins \& Maurer, 2010: 1780; see also Szreter \& Woolcock, 2004). Such hierarchical relationships are often established by practitioners in organizations that position themselves between citizens in disadvantaged neighborhoods and local government (de Graaf et al., 2015).

\section{The policy context}

Many neighborhood organizations receive some form of funding from the state, since the state supports volunteering groups (e.g. Bosch, 2016) or contracts neighborhood organizations to provide welfare services to the unemployed or low-income individuals (Smith \& Lipsky, 1993). In recent decades, welfare state transformations have changed the mediating role of neighborhood organizations. Three related trends indicate in what ways this role has been redefined. First, the aim of many welfare reforms is decentralization, meaning public services provided by the nation state are delegated to local governments, communities, and civic organizations (Andreotti et al., 2012; Kazepov, 2008). These local bodies should have more local knowledge and capability to perform public tasks and therefore receive more financial resources although the latter does not always occur since decentralizations of public tasks are frequently motivated by cutbacks (e.g. Fenger \& Broekema, 2019; Lowndes \& Pratchett, 2012). The underlying assumption of decentralization is that local bodies are more effective in service delivery, have more democratic legitimacy, and are more financially sustainable (Andreotti et al., 2012). Second, decentralization is accompanied by the responsibilization of local bodies and citizens. Responsibilization refers to a shift in responsibility for public tasks from the nation state to local bodies and citizens (see Schinkel \& van Houdt, 2010). The implication is that the nation state is no longer primarily responsible for people's welfare. Instead, citizens are expected to bear responsibility for their personal welfare (e.g. 
employment, health, finances) and their environment, which is promoted as 'active citizenship' (Verhoeven \& Tonkens, 2013). Third, social innovation has become a popular concept in response to the shortcomings of the traditional welfare state. We follow Oosterlynck et al. (2013:3) in understanding social innovation as: “... locally embedded practices, actions and policies that help socially excluded and impoverished individuals and social groups to satisfy basic needs for which they find no adequate solution in the private market or macro-level welfare policies."

In the context of neighborhood development, social innovation is mainly practiced by resident collectives that aim to meet the social needs of people in marginalized and diverse areas (Moulaert et al., 2010). Through co-operation with supra-local actors, networks, and institutions, these initiatives can be upscaled and transferred to other local contexts and thus structurally transform society (Oosterlynck et al. 2013: 3). Taken things together, neighborhood organizations, as meso-level institutions, have thus become more important in the past decades as part of a governance structure (cf. McQuarrie \& Marwell, 2009).

Two particular Dutch social policies, characterized by decentralization, responsibilization, and social innovation, affect the organizations and individuals in our study. The first policy results from a national law introduced, the Participation Act, which was introduced in 2015. Under the Participation Act, social assistance recipients are required to do 'something useful for society' in return for receiving social benefits (Fenger \& Broekema, 2019; cf. Mead, 1986). These reciprocal acts may include activities such as community work, volunteering, attending a language course or participating in a health program. Responsibility for policy implementation has been devolved to municipalities, who thus determine what social assistance recipients should do in return for their benefits. Recipients who do not comply run the risk of temporarily losing their benefits.

Rotterdam became known as one the strictest enforcers of the Participation Act due to a coalition between 2014 and 2018 in which the local populist-right party Leefbaar Rotterdam (Liveable Rotterdam) was the largest party (cf. Uitermark \& Duyvendak, 2008). In public discourse a general distrust was 
displayed towards the unemployed and the necessity of having paid work was continuously emphasized. The local policy variant of the Participation Act is called the 'Reciprocity Policy'. Social assistance recipients are primarily held responsible for finding a job and those unable to work must determine what their 'societal contribution' will be (cf. Veldboer et al., 2015). If their proposal is considered insufficient by the welfare department, a welfare officer determines an appropriate mandatory activity. Social assistance recipients are also monitored to ascertain whether they are fulfilling their tasks accordingly. Moreover, the municipality appeals to civic organizations, including many neighborhood organizations, to help with 're-activating' social assistance recipients who have been inactive for some time. Recipients who are already doing voluntary work are also re-evaluated to ascertain their ability to perform paid work. Thus, whereas the pressure on social assistance recipients to 'give back' is increasing, neighborhood organizations are facing increased demands from the municipality to facilitate this group (Kampen et al., 2019).

Whereas the Reciprocity Policy clearly includes aspects of decentralization and responsibilization, the second social policy in Rotterdam that is relevant for this study is related to social innovation. In 2015 the municipality founded CityLab010, a yearly subsidy of 3 million euros that is distributed between initiatives with innovative ideas for 'solving societal issues in Rotterdam'. Citizens or organizations can submit a project plan for tackling societal issues such as social cohesion, the energy transition or equal opportunities. After the submission deadline, a jury decides which citizens or organizations will receive a budget for developing their initiative. The philosophy behind this policy is that the 'city' has more innovative capability than the municipality to solve societal issues. The policy thus assumes that citizens or local organizations are better equipped and more creative than government to organize certain public services (cf. Custers et al., 2019; Oosterlynck et al., 2013; Uitermark, 2015). 


\section{Data and method}

We use the COREQ checklist by Tong et al. (2007) to describe our data collection and analysis. This checklist was designed to promote explicit and comprehensive reporting of qualitative studies, which thus provides a more formal way to clarify how qualitative research was conducted.

Research team - the research team consisted of the two authors and three student-assistants who used the collected data for writing their master thesis. The student-assistants conducted interviews with participants in three neighborhood organizations and when possible, additional participant observation was carried out. At a later stage in the research process, a second interview with the leader of every organization was conducted by the first author. During data collection, the first author was employed as a $\mathrm{PhD}$ researcher and the second author was a full professor in Sociology. The two authors are both male and the three student-assistants are all female. The student-assistants received interview training from the authors. The general principles of interviewing were discussed and mock interviews were held on which the student-assistants received feedback.

Study design - the theoretical framework and methodological orientation that underpin our study are based on the adaptive theory approach by Layder (1998). Adaptive theory endeavors to combine the use of pre-existing theory and theory generated from data analysis in the formulation and actual conduct of empirical research (Layder, 1998: 2). It can be seen as a middle position between deductive or theorytesting approaches on the one hand and inductive or theory-generating approaches on the other.

The initial research idea was to investigate how neighborhood organizations help residents gain employment and how they provide daily structure for unemployed or economically non-active residents, for example through facilitating volunteer work. A main goal was to study the dynamics of different neighborhood organizations, since organizations differ in their capability to address several social needs. Convenience sampling was used to select three neighborhood organizations in low-income neighborhoods, as the student-assistants were already acquainted with these organizations. Two criteria 
for selection, however, were that the organizations differed in nature and met the definition given in theory section. We therefore have a mix of organizations in our study, including a faith-based center ('Faith Center'), a professional welfare organization ('Top Job'), and a volunteer-based organization ('Neighbor Spot').

Access to the organizations was gained through establishing contact with key persons in the organizations, who also acted as key informants during the research. They were either the leader of the organization or held important management positions (from here on: leaders). Snowball sampling was used to interview the most active or frequently visiting participants in every organization. Most interview requests were made face-to-face, when the student-assistants were visiting the organization. This process continued until theoretical saturation was reached. Only a few potential respondents declined interview requests because they were not interested, shy or lacked trust. In total, 34 interviews were conducted by student-assistants, including with the leaders: 17 in the faith-based center, 5 in the professional welfare organization, and 12 in the volunteer-based organization. ${ }^{2}$ In addition, the first author held three follow-up interviews with the leaders to discuss issues that had emerged after initial analysis of the data. All interviews took place at the organizations, nearly always in a separate space where privacy was assured. ${ }^{3}$ A list of respondents, including their age and gender, is provided in the Appendix (Table A1).

The interviews were semi-structured to ensure the same topics were covered in every interview while allowing flexibility to follow up relevant themes that might emerge (Mason, 2004). An interview guide was developed with topics and questions of interest, including how respondents joined the organization, their role in the organization, what their participation meant to them, their relations with other active members, and the significance of the organization for their daily life. Interviews with the leaders were set up differently. The student-assistants mainly focused on the operation and goals of the organization and the personal motivation of the leaders. Guided by theoretical interest and a discussion of the initial data, the follow-up interviews with the leaders also discussed policy and organizational ties. The student-assistants were encouraged to make field notes during activities of the faith-based center and 
the professional welfare organization, since these organizations ran regular programs for their participants.

Data analysis - The interviews were audio recorded and transcribed by the student-assistants. Field notes were also written in digital format. The transcripts were coded and analyzed by the first author using ATLAS.ti software. In line with the adaptive theory approach we constructed several codes before analyzing the data. Theoretical interest guided our main codes, which included 'entry organization', 'ties in organization', 'give or receive support', 'daily occupation', 'work aspiration', 'motivation participation', 'benefits participation', 'connection neighborhood', 'Reciprocity Policy', and 'social benefits'. During the analysis, open coding was applied to identify any emerging themes. After initial coding, all codes were evaluated and merged with other codes when relevant. In this step, 'links to other organizations', 'problems municipality', 'mediate contact', 'funding', 'stay busy', 'routine', 'faith', 'community', 'increase network', 'gain confidence', 'personal growth', and 'multicultural' were identified as important codes. In the next step, the codes were ordered into the following theme groups: fostering relations, providing structure, ties to other organizations, and policy. Codes could be grouped under multiple themes. For example, 'funding' relates both to organizational ties and policy. In addition, some specific codes from the initial coding phase were retained when more insight into a theme was needed.

\section{Results}

Table 1 presents an overview on the distinctive characteristics of each organization. This overview provides a first indication that the organizations substantially differ in size, type of participants and daily goals. For instance, whereas Faith Center aims to build community across people from different backgrounds, Top Job trains people so that they might regain labor market access. Neighbor Spot, on the other hand, is a local help center run by volunteers where residents can ask questions about housing, debts 
and other social issues. We do note that almost none of our respondents had a fulltime job. They were either employed part-time or economically inactive (e.g. unemployed, on social assistance, household work, retired), which means they were able to spend a significant amount of time at the organization. Through this analytic lens, we find that all organizations profoundly shape the lives of their participants while they also considerably differ in how this impact crystalizes.

[Table 1 here]

\section{Fostering relations and providing structure}

We first analyzed the organizations in how they foster social relations between participants, paying attention to how people joined the organization and what kind of relations they developed. From this perspective there is somewhat a dichotomy between Faith Center, where ties are strong and durable, and the other two organizations in which ties are looser and more temporary. Faith Center creates a strong sense of community amongst its members. The weekly activities (communal breakfasts, dinners, religious services, language lessons) ensure that many people visit the organization regularly, which offers opportunities for repeated interaction. New members mostly join through personal networks, but the Protestant pastor Dave (early fifties, male) also encourages members to actively recruit outsiders. This strategy helped counter social isolation amongst some respondents who joined the organization. For instance, Rick, a retired male, met two members at a flea market and they invited him to a religious service:

"They said 'come with us, it is very nice' and all that. She picked me up and I was nervously shaking ... then I saw some familiar faces and ... I immediately felt I belonged here. ... They took care of me and I noticed that I belonged here, that I was no loner ..." 
Active members keep an eye out for each other. Whenever a regular visitor is absent, others will inquire about his or her situation. This habit is appreciated amongst many members, as Nima (late twenties, female) illustrates: "I was not there one Sunday ... everybody missed me, and I find that very important".

Faith Center connects people from different backgrounds, especially with regards to ethnicity and religion, as the communal meals have a low threshold. This increases mutual understanding between different groups in the neighborhood, although some struggles over multiculturalism remain. Rick exemplified this issue when he was asked about perceived differences in the organization:

“Look I don't want to discriminate or anything, but ... I think the darker women walk past me quicker because I am a white old male. ... I think that is a bit unfortunate, since we come here with the same purpose [to eat together and chat with others]".

At Neighbor Spot there is more of a collegial atmosphere. Most volunteers know each other well and sometimes they meet up outside of the organization, but the sense of community is much lower compared to Faith Center. Top Job brings participants together for a brief period, but during this period repeated interaction occurs. The training program lasts five weeks during which participants take part in different activities, such as social media training, workouts and resume building. During the program they developed a strong sense of 'us' because they were 'in it together'. Participants perceived the group as cohesive, which Dirk (mid-forties, male) describes as follows:

“... if somebody did not know something, then someone else would help you. That is nice about the group. I mean, having each other's back, the cooperation, leaving no person behind. This is what you learn when you work in a team and how to do it."

Yet, since no regular meetings were held after the program, the strong bond between the participants ceased after some time. Participants stayed in touch though through a WhatsApp group, which they use to send each other job offers. 
When we consider how the organizations structure the daily life of participants, we see that all organizations are important in shaping their daily routine. For Faith Center, Nima exemplifies how the organization provides a daily occupation for those unable to perform paid work:

"This is my daily life. I have no job, so if I did not have Faith Center I would sit at home all day ... This provides me with an occupation and structure that enable me to enjoy life."

In general, Faith Center increases ‘societal participation' by drawing people into the organizational sphere and broadening their social network. Top Job also focuses on activating respondents, although the program works more like a 'shock' effect. Mark (late twenties, male), the leader of the program, explains that the program requires major adjustments to the daily lives of some participants, since some have been unemployed for many years. The lack of structure before Top Job is illustrated by Dirk: "Normally you would get up around half past ten, make a cup of coffee and go sit in front of the television, and then wait until you can go to bed again". Ronald (mid-twenties, male) further describes how the program activated the participants: "The first week everybody was very tired and lazy, you had no rhythm basically.

Gradually everybody became more fit and things went easier. You could see everybody flourished, which was a good thing for everybody”. Most members in Neighbor Spot perform voluntary work, meaning their volunteering acts as an unpaid occupation (cf. Baines \& Hardill, 2008). The main group of volunteers consists of women who 'work at the counter'. They receive residents who have a question or issue and subsequently help them any way possible. These volunteers work several days a week and view it as their main occupation. The second group mainly consists of retired men who take care of administrative tasks such as financial administration, subsidy applications, and chairing meetings. Their involvement is less time-consuming on average. Both groups, however, frame their engagement in a similar way. Many state they 'do not want to sit at home' and they 'want to be or stay busy', as Sanna (middle-aged, female) for example tells when asked why she became a volunteer: “Just to get to work. I am really not that person to sit at home. I really could not do that." 


\section{Ties to other organizations}

An important theme that emerged during our fieldwork was that these organizations are well-connected to other organizations and their ties are beneficial to their participants. Faith Center has many 'networkpartners', as the pastor calls them. These partners include schools, welfare organizations, the neighborhood team ${ }^{4}$, social housing corporations, and the municipality. Cooperation with these organizations takes different forms. In some cases, Faith Center receives a discount in return for certain services. For example, Faith Center rents space from a social housing corporation where the communal breakfasts and dinners take place. At the same time, a group of young people who belong to Faith Center rent student dorms from this housing corporation. The youngsters receive a discount on their rent when they perform certain informal jobs, such as organizing a block party or adopting a trash container. ${ }^{5}$ This discount is used to pay the rent for the communal space, which all members of Faith Center can use. Another example of cooperation are the language and swimming lessons for a group of Muslim women. These lessons are organized together with two welfare organizations, so that the responsibility and resources can be shared between the organizations.

Top Job has several ties with local entrepreneurs and businesses, which is quite unusual for a welfare organization. These ties are maintained through a close relationship with The Company Center, a local platform for employers. The neighborhood where Top Job operates is near many businesses, since it lies adjacent to a large industrial area. However, as Mark explains, having connections alone is insufficient to help his clients obtain employment. Therefore, he developed the program together with Harry from The Company Center to get his clients 'job-ready'. Multiple training sessions, such as social media lessons or job interview instructions, are provided by local employers, often at a reduced rate. At the end of the program, the employers attend an event where certificates are handed out and elevator pitches are given. During this event they possibly recruit one of the candidates. Another advantage of Top Job is being part of a larger welfare organization, which extends its network to employers in other parts of the city. Reputational management is a central aspect in dealing with local employers, as Mark points out: 
"I visit a lot of companies. Just to check how that person is doing. Or I make a call. It is all very strategic of course, that is how it works. Look, if I send someone to a company who then completely screws up and then I would send another person ... my name and Top Job's is on the line. Therefore, I am always critical ... if I think, this is not going to work, then I wait and slow down the process."

Ties to other organizations are essential for Neighbor Spot as well. The volunteers particularly mention their 'short lines' to several organizations such as the social housing corporation, the municipality, and the neighborhood team. Multiple examples were given during the interviews. One example includes elderly migrants who often lack certain language and digital skills that are needed to fill in forms. In these cases, a volunteer helps with these forms and sends them to the relevant organization. Another example is 'taxes day'. Every year Neighbor Spot organizes an afternoon where people can get help with filing their taxes. Residents can therefore communicate more efficiently with the national tax department. Volunteers at Neighbor Spot are proud of their 'personal approach', which according to them works better than the 'impersonal' municipality helpline. As with Top Job, reputation plays an important role. When Laura (early 50s, female), the head of volunteers, calls the municipal welfare department, they often recognize her name and then 'things get done quicker'. Furthermore, the working-age volunteers at Neighbor Spot use the organization's network to keep track of job vacancies, as some aspire to obtain a paid job. People at connected organizations may then vouch for one of the volunteers. Maria (midtwenties, female) illustrates how this process works:

"If you go via via ... then it works. If you have somebody there [at another organization] that you know and that person says 'she is very good in this and that' and then you apply, you are on top of the list because you are already introduced so to say. I went to many job interviews this way."

A general observation that can be made concerning organizational ties is that individual leadership seems crucial in forming and maintaining these ties. Dave, Mark, and Laura all devote a great deal of energy to managing the network and reputation of their organization. As either the leader or operational manager, they are also the individuals with whom the organization is associated - especially 
since all three organizations are rather small. Moreover, many participants in the organizations do not have the abilities required to provide leadership, which thus creates dependency on individuals such as Dave, Mark, and Laura.

\section{Policy practices and effects}

Municipal policy has distinctive effects on the organizations and in some cases on their individual participants as well. In relation to the municipality, Faith Center is a relatively autonomous organization. It receives most funding from charities and other Protestant congregations, which requires it to maintain a high public profile. Its relative independence from the municipality does not mean that Faith Center does not engage with local policy. One of its struggles is to be acknowledged as a 'mature' organization that can provide social services of the same quality as professional welfare organizations. This issue was raised when the relation with the municipal welfare department was discussed with the pastor. Multiple participants in Faith Center are obliged to 'make a societal contribution' due to the Reciprocity Policy, but Faith Center is not always acknowledged as a legitimate organization for fulfilling such obligations. Nevertheless, the pastor feels that Faith Center has a responsibility to take care of those who have been neglected by the government. He sees that people are often treated as 'second class citizens' by social professionals and therefore he wants people to once more feel that they matter.

Top Job exemplifies how social innovation can be stimulated by government. Through Citylab010 the municipality provided Top Job with the funds it needed to design the program together with its business partners, without interfering in the process. The nature of the funding also made it possible to bridge the segmented worlds of 'work' and 'welfare', as these worlds frequently constitute different policy domains. Furthermore, if the program would have failed, there would have been few consequences for Top Job, save the damage to its reputation. A drawback, however, is that Citylab010 only provides a one-off contribution. Therefore, during the time of our research Mark still had to secure structural funds from a different source in order to continue the program. In addition, individual 
participants in the Top Job program evidently benefited from the CityLab010 policy. According to Mark, most participants obtained a job with a permanent contract after the program. Since many participants had struggled with job security before the program, the municipality's innovation policy indirectly transformed their lives.

Like Faith Center, Neighbor Spot receives no direct financial support from the municipality. The organization deals with social policy in many ways because, next to representing residents on a social housing committee, the complexity and fragmentation of local social policy is its 'raison d'être'. But the fact that the effects of the Reciprocity Policy were mainly manifest at the individual level led to mixed feelings among the most active volunteers. On the one hand, they have extensive knowledge of how social policy works and they use this knowledge to help other residents navigate the system world of bureaucratic organizations (de Graaf et al., 2015). As mentioned before, they are proud to fulfill this 'linking' role. Most volunteers in this group emphasize that their volunteer work also counts as 'employment' (Baines \& Hardill, 2008), thereby referring to the skills one needs to work at Neighbor Spot - e.g. knowledge of social policies, communication skills, and basic computer skills. They feel that the outside world does not always take them seriously. Laura expresses this view as follows:

"I keep fighting against it. It is not only my environment; it is the whole world. A volunteer is not a professional and I fight the hardest against that. The only difference between me and a professional is that a professional gets good pay, I do it for my social benefits"

On the other hand, discussions about the Reciprocity Policy evoked strong responses among some of the volunteers in this group, who are personally affected by the policy. After meeting with their welfare officers, they feel their voluntary work is worth less since 'everybody has to do it now'. They also believe the welfare department does not fully appreciate the work they are already doing. Some volunteers were criticized or questioned by their welfare officer whereas others experienced no problems. This contingency leads to feelings of unfairness among some of the volunteers. However, the need to 'do something in return' for receiving social assistance is endorsed by the volunteers, which is also 
accompanied by boundary work (Kampen et al., 2019). The volunteers made a distinction between 'active' types like themselves and 'non-active' people for whom some stimulus is needed to become an 'active citizen'.

\section{Conclusion and discussion}

This study has shown how different neighborhood organizations shape the lives of various groups in lowincome neighborhoods. Our conclusion is divided into three parts. The first two parts discuss how our empirical findings relate to theory about organizational effects and policy effects, respectively. The last part provides a reflection on the relevance of neighborhood organizations for neighborhood effects studies.

First, the type of the neighborhood organization affects how people develop relations, which was especially reflected in how Faith Center connects different groups in the neighborhood. This faith-based organization offers a low threshold for participation and encourages outsiders to join activities. Ethnic and religious differences are transcended during communal meals (cf. Wessendorf, 2014), which is quite exceptional as many local organizations in Rotterdam are organized along ethnic lines (Bosch, 2016; cf. Pinkster, 2007). The effect of Faith Center on social cohesion in the neighborhood seems quite substantial, since about 150 people frequently participate in the communal activities. It shows how organizations may contribute to cohesion at the neighborhood level, though this effect can still be selective as bridging ties between residents were formed in terms of ethnicity and religion but not from a social class perspective.

Different elements of Jahoda's (1982) latent functions of employment can be recognized in the neighborhood organizations. Top Job stands out in imposing a rigid time structure on participants who previously had little structure. The program also inspires the idea that participants are working together towards a common goal, that is, their increased employability. A key issue in Neighbor Spot is how the 
volunteer work is valued by the 'outside' world - relating to how employment is associated with status and identity. Some of the volunteers consider it as 'work' that does not differ from paid work, but they frequently notice that people outside the organization hold different views (cf. Baines \& Hardill, 2008).

Our findings provide further insight into how organizational ties directly benefit participants, an issue that has received little attention in the urban studies (Small, 2009). The analysis shows how each organization has their own specific set of ties and thereby how organizational type potentially determines what resources can be brokered. Faith Center has several contacts with welfare organizations in the neighborhood, which helps its participants to access welfare services. Moreover, the pastor has invested in linking social capital with wealthier congregations and charities that Faith Center can use to acquire financial resources (Szreter \& Woolcock, 2004). Being part of the Top Job program gives participants the advantage of having access to multiple employers, whereas Neighbor Spot possesses linking social capital that can used to mediate between vulnerable residents and bureaucratic organizations such as the municipality or the social housing corporation (cf. Marwell, 2007).

Second, our analysis reveals how trends towards decentralization, reponsibilization, and social innovation crystallize in the practices of neighborhood organizations. Top Job demonstrates how the implementation of active labor market policy is devolved to a local welfare organization. Responsibility for completing the program and obtaining a job is strongly framed in terms of individual achievement (Verhoeven \& Tonkens, 2013). The candidates are expected to put in the effort in order to be successful. The program, however, offers a diverse and intense training that is not available to most unemployed people. The success of the candidates might thus be the result of the program's structure rather than the candidates' motivation. Furthermore, while not receiving any direct financial compensation from the municipality, Neighbor Spot has taken over its responsibility to help residents obtain the appropriate welfare services - normally residents should use the municipal helpline. Our results indicate that the individual responsibilization of welfare can also have harmful and unintended consequences as the selfimage of some volunteers has been negatively affected by the Reciprocity Policy. They felt that their 
voluntary work was worth less following the introduction of this policy (Kampen et al., 2019; Veldboer et al., 2015).

Features of social innovation were clearly present in Faith Center and Top Job. Through active recruitment and a focus on building an inclusive community, Faith Center aims to transform relations between different groups by showing that 'faith' can be a binding force. This transformation is, however, not a result of social policy, but rather of actions taken by the pastor who receives support from other Protestant congregations. In contrast, Top Job's innovative program is driven by social policy (CityLab010). Yet, its location nearby industry, the local network of employers, Mark's networking skills, and the costs of the program are all factors that cannot easily be transferred to other contexts. The potential to upscale the program thus seems limited given the specific conditions that constitute its success (Moulaert et al., 2010; Oosterlynck et al., 2013).

Third, previous neighborhood effect studies have shown that the organizational infrastructure of neighborhoods can explain why social capital is higher in some neighborhoods, partly independent of neighborhood socioeconomic status (e.g. Gilster, 2017). However, such studies that quantify the influence of neighborhood organizations often cannot specifically indicate which organizations contribute to social capital in the neighborhood and in what ways. They often aggregate neighborhood organizations into an index, treating them as the sum of various elements (e.g. Curley, 2010b). Our study therefore contributes to this literature by showing that different types of neighborhoods organizations can have distinct effects on the neighborhood. For instance, if we imagine a neighborhood with many organizations similar to Faith Center, the effect on local social cohesion and reduced loneliness would likely be profound. In a similar vein, a neighborhood with many organizations like Top Job would have positive effects on labor market outcomes. Hence, it is important to distinguish the different theoretical pathways through which different organizations are expected to have impact on the neighborhood (Galster, 2012).

We conclude with some limitations of our study. The neighborhood organizations were selected through convenience sampling using the network of our student-assistants. The findings should therefore 
not be interpreted as representative of these types of organizations, although it would be interesting to see if similar organizations affect their participants in the same way. The same applies to how organizations dealt with the municipal policies. We showed that some ambiguity exists with respect to how the Reciprocity Policy is received, but based on our study we cannot fully grasp the impact of this policy on local organizations. In addition, we conducted our investigation with a focus on how these organizations potentially contribute to the lives of their participants. Yet, this focus does not rule out that more subtle processes of social exclusion might have been at work. Such forms of social exclusion might, for instance, include that people do not feel welcome in an organization or have left for other reasons. Nonparticipation of the urban poor can also be the result of a negative stigma associated with specific neighborhood organizations (cf. Lipsky, 2010). Thus, even though we have shown that our organizations have positive effects on their participants in general, it is possible we omitted some more negative effects. 


\section{References}

Allard, S. W., \& Small, M. L. (2013). Reconsidering the urban disadvantaged: The role of systems, institutions, and organizations. The ANNALS of the American Academy of Political and Social Science, 647(1), 6-20.

Andreotti, A., Mingione, E., \& Polizzi, E. (2012). Local welfare systems: A challenge for social cohesion. Urban Studies, 49(9), 1925-1940.

Anheier, H. (2005). Nonprofit organizations: Theory, management, policy. Routledge.

Baines, S., \& Hardill, I. (2008). 'At least I can do something': The work of volunteering in a community beset by worklessness. Social Policy and Society, 7(3), 307-317.

Bosch, E. (2016). “Self-organization” of welfare-services in deprived and wealthier urban neighborhoods in the Dutch participation society. Università degli Studi di Milano-Bicocca.

Curley, A. M. (2010). Neighborhood institutions, facilities, and public space: A missing link for Hope VI residents' development of social capital? Cityscape, 12(1), 33-63.

Curley, A. M. (2010). Relocating the poor: Social capital and neighborhood resources. Journal of Urban Affairs, 32(1), 79-103.

Custers, G. (2019). Neighbourhood ties and employment: A test of different hypotheses across neighbourhoods. Housing Studies, 34(7), 1212-1234.

Custers, G., Engbersen, G., \& Snel, E. (2019). The economic recession and civic participation: The curious case of Rotterdam's civil society, 2008-2013. The British Journal of Sociology, 70(5), 1946-1970. 
de Graaf, L., van Hulst, M., \& Michels, A. (2015). Enhancing participation in disadvantaged urban neighbourhoods. Local Government Studies, 41(1), 44-62.

Fenger, M., \& Broekema, B. (2019). From welfare state to participation society: Austerity, ideology or rhetoric? In E. Heins, C. Needham, \& J. Rees (Eds.), Social policy review 31: Analysis and debate in social policy 2019 (pp. 101-124). Policy Press.

Galster, G. (2012). The mechanism(s) of neighbourhood effects: Theory, evidence, and policy implications. In M. van Ham, D. Manley, N. Bailey, L. Simpson, \& D. Maclennan (Eds.), Neighbourhood effects research: New perspectives (pp. 23-56). Springer.

Gilster, M. E. (2017). The spatial distribution of organizational resources and resident participation in civic life in Chicago neighborhoods. Social Service Review, 91(2), 264-292.

Hawkins, R. L., \& Maurer, K. (2010). Bonding, bridging and linking: How social capital operated in New Orleans following hurricane Katrina. British Journal of Social Work, 40(6), 1777-1793.

Jahoda, M. (1982). Employment and unemployment: A social-psychological analysis. Cambridge University Press.

Kampen, T., Veldboer, L., \& Kleinhans, R. (2019). The obligation to volunteer as fair reciprocity? Welfare recipients' perceptions of giving back to society. VOLUNTAS: International Journal of Voluntary and Nonprofit Organizations, 30(5), 991-1005.

Kazepov, Y. (2008). The subsidiarization of social policies: Actors, processes and impacts. European Societies, 10(2), 247-273.

Klinenberg, E. (2015). Heat wave: A social autopsy of disaster in Chicago. University of Chicago Press.

Layder, D. (1998). Sociological practice: Linking theory and social research. SAGE. 
Letki, N. (2008). Does diversity erode social cohesion? Social capital and race in British neighbourhoods. Political Studies, 56(1), 99-126.

Lipsky, M. (2010). Street-level bureaucracy: Dilemmas of the individual in public service. Russell Sage Foundation.

Lowndes, V., \& Pratchett, L. (2012). Local governance under the coalition government: Austerity, localism and the 'Big Society.' Local Government Studies, 38(1), 21-40.

Marwell, N. P. (2007). Bargaining for Brooklyn: Community organizations in the entrepreneurial city. University of Chicago Press.

Mason, J. (2004). Semistructured interview. In M. Lewis-Beck, A. E. Bryman, \& T. F. Liao (Eds.), The SAGE encyclopedia of social science research methods (Vol. 2, pp. 1020-1022). SAGE.

McQuarrie, M., \& Marwell, N. P. (2009). The missing organizational dimension in urban sociology. City \& Community, 8(3), 247-268.

Mead, L. M. (1986). Beyond entitlement: The social obligations of citizenship. The Free Press.

Miltenburg, E. (2015). The conditionality of neighbourhood effects upon social neighbourhood embeddedness: A critical examination of the resources and socialisation mechanisms. Housing Studies, 30(2), 272-294.

Moulaert, F., Swyngedouw, E., Martinelli, F., \& Gonzalez, S. (2010). Can neighbourhoods save the city? Community development and social innovation. Routledge.

Nast, J., \& Blokland, T. (2014). Social mix revisited: Neighbourhood institutions as setting for boundary work and social capital. Sociology, 48(3), 482-499. 
Oosterlynck, S., Kazepov, Y., Novy, A., Cools, P., Barberis, E., Wukovitsch, F., \& Leubolt, B. (2013). The butterfly and the elephant: Local social innovation, the welfare state and new poverty dynamics (ImPRovE Discussion Paper, No. 13/03; ImPRovE Discussion Paper). Herman Deleeck Centre for Social Policy - University of Antwerp.

Pinkster, F. M. (2007). Localised social networks, socialisation and social mobility in a low-income neighbourhood in the Netherlands. Urban Studies, 44(13), 2587-2603.

Pinkster, F. M. (2009). Neighbourhood-based networks, social resources, and labor market participation in two Dutch neighbourhoods. Journal of Urban Affairs, 31(2), 213-231.

Rich, R. C. (1979). The roles of neighborhood organizations in urban service delivery. Journal of Urban Affairs, 1(1), 81-93.

Sampson, R. J. (2012). Great American city: Chicago and the enduring neighborhood effect. University of Chicago Press.

Schinkel, W., \& van Houdt, F. (2010). The double helix of cultural assimilationism and neo-liberalism: Citizenship in contemporary governmentality. The British Journal of Sociology, 61(4), 696-715.

Sharkey, P., \& Faber, J. W. (2014). Where, when, why, and for whom do residential contexts matter? Moving away from the dichotomous understanding of neighborhood effects. Annual Review of Sociology, 40, 559-579.

Slater, T. (2013). Your life chances affect where you live: A critique of the 'cottage industry' of neighbourhood effects research. International Journal of Urban and Regional Research, 37(2), 367387. 
Small, M. L. (2009). Unanticipated gains: Origins of network inequality in everyday life. Oxford University Press.

Smith, S. R., \& Lipsky, M. (1993). Nonprofits for hire: The welfare state in the age of contracting. Harvard University Press.

Szreter, S., \& Woolcock, M. (2004). Health by association? Social capital, social theory, and the political economy of public health. International Journal of Epidemiology, 33(4), 650-667.

Tong, A., Sainsbury, P., \& Craig, J. (2007). Consolidated Criteria for Reporting Qualitative Research (COREQ): A 32-item checklist for interviews and focus groups. International Journal for Quality in Health Care, 19(6), 349-357.

Uitermark, J. (2015). Longing for Wikitopia: The study and politics of self-organisation. Urban Studies, 52(13), 2301-2312.

Uitermark, J., \& Duyvendak, J. W. (2008). Civilising the city: Populism and revanchist urbanism in Rotterdam. Urban Studies, 45(7), 1485-1503.

van Bergeijk, E., Bolt, G., \& Van Kempen, R. (2008). Social cohesion in deprived neighbourhoods in the Netherlands: The effect of the use of neighbourhood facilities. Annual Meeting of the Housing Studies Association, York, UK.

van Eijk, G. (2010). Does living in a poor neighbourhood result in network poverty? A study on local networks, locality-based relationships and neighbourhood settings. Journal of Housing and the Built Environment, 25(4), 467-480. 
van Kempen, R., \& Wissink, B. (2014). Between places and flows: Towards a new agenda for neighbourhood research in an age of mobility. Geografiska Annaler: Series B, Human Geography, 96(2), 95-108.

Veldboer, L., Kleinhans, R., \& van Ham, M. (2015). Mandatory volunteer work as fair reciprocity for unemployment and social benefits? (IZA Discussion Papers, No. 9111; IZA Discussion Papers, No. 9111). Institute for the Study of Labor (IZA).

Verhoeven, I., \& Tonkens, E. (2013). Talking active citizenship: Framing welfare state reform in england and the netherlands. Social Policy and Society, 12(3), 415-426.

Wessendorf, S. (2014). 'Being open, but sometimes closed'. Conviviality in a super-diverse London neighbourhood. European Journal of Cultural Studies, 17(4), 392-405.

\section{Notes}

1. We do not claim that neighborhood organizations only fulfill these functions for the economically inactive. Social professionals, who usually act as leaders of neighborhood initiatives, can also be found as active members in many organizations (see Bosch, 2016).

2. We have two reasons why the number of interviews considerably differs between organizations. First, in the faith-based center eight interviews were conducted with women who had limited mastery of the Dutch language. These interviews were therefore relatively short, about 20 minutes on average. Furthermore, the number of participants in the professional welfare organization was small due to the structure of the program. Combined with multiple participatory sessions, five interviews were sufficient to reach theoretical saturation.

3. The data were collected between April and June in 2017. 
4. These teams are an interdisciplinary mix of welfare professionals (e.g. nurses, general practitioners, neighborhood managers, community workers).

5. Adopting a container means someone accepts responsibility to keep the area around this container clean and tidy.

\section{Appendix}

Table A1. List with interviewees

\begin{tabular}{|c|c|c|c|}
\hline $\begin{array}{l}\text { Name respondent } \\
\text { (pseudonym) }\end{array}$ & Organization & Sex (male/female) & Age \\
\hline Tabatha & Faith Center & female & 33 \\
\hline Sofia & Faith Center & female & 61 \\
\hline Sarah & Faith Center & female & 54 \\
\hline Rima & Faith Center & female & 34 \\
\hline Nora & Faith Center & female & 40 \\
\hline Mila & Faith Center & female & 35 \\
\hline Loubna & Faith Center & female & 47 \\
\hline Gadisa & Faith Center & female & 55 \\
\hline Chadia & Faith Center & female & 38 \\
\hline Sannah & Faith Center & female & 49 \\
\hline Rick & Faith Center & male & 69 \\
\hline Dave (pastor) & Faith Center & male & 51 \\
\hline Nima & Faith Center & female & 29 \\
\hline Milou & Faith Center & female & 48 \\
\hline Hudson & Faith Center & male & 40 \\
\hline Harianne & Faith Center & female & 58 \\
\hline Brigitte & Faith Center & female & 50 \\
\hline Mark (program leader) & Top Job & male & 29 \\
\hline Dirk & Top Job & male & 43 \\
\hline Ronald & Top Job & male & 24 \\
\hline Aycan & Top Job & female & 45 \\
\hline Pieter & Top Job & male & 45 \\
\hline Laura (manager) & Neighbor Spot & female & 51 \\
\hline Dorien & Neighbor Spot & female & 37 \\
\hline Marjorie & Neighbor Spot & female & 35 \\
\hline Maria & Neighbor Spot & female & 26 \\
\hline Sanna & Neighbor Spot & female & 41 \\
\hline Xenia & Neighbor Spot & female & 55 \\
\hline Casper & Neighbor Spot & male & 69 \\
\hline
\end{tabular}




\begin{tabular}{llcc} 
Ferry & Neighbor Spot & male & 70 \\
Gerard & Neighbor Spot & male & 66 \\
Jan & Neighbor Spot & male & 73 \\
Kashia & Neighbor Spot & female & 51 \\
Laetitia & Neighbor Spot & female & 45 \\
\hline
\end{tabular}

\section{Tables}

Table 1. Overview neighborhood organizations

\begin{tabular}{lccc}
\hline Name & Faith Center & Top Job & Neighbor Spot \\
\hline Type of organization & Faith-based & Professional welfare & Volunteer-based \\
Type of societal participation & $\begin{array}{c}\text { Countering social } \\
\text { isolation, community } \\
\text { building, volunteering }\end{array}$ & Labor market re-entry & Voluntary work \\
$\begin{array}{l}\text { Number of active participants } \\
\text { (estimated) }\end{array}$ & 150 & 10 & 15 \\
$\begin{array}{l}\text { Idiosyncratic characteristics of } \\
\text { participants }\end{array}$ & $\begin{array}{c}\text { Ethnically diverse, low } \\
\text { socioeconomic status, } \\
\text { non-working }\end{array}$ & $\begin{array}{c}\text { (Long-term) } \\
\text { unemployed }\end{array}$ & $\begin{array}{c}\text { Social assistance } \\
\text { recipients, retirees }\end{array}$ \\
\hline
\end{tabular}

